\title{
Biyoloji Öğretmen Adaylarının Kavram Yanılgılarının Belirlenmesi ve Giderilmesi Üzerine Bir Eylem Araştırması
}

\author{
Merve Adıüzel ${ }^{1}$, Mehmet Yılmaz $^{2}$
}

\footnotetext{
${ }^{1}$ Matematik ve Fen Bilimleri Ĕgitimi Anabilim Dal, Eğitim Bilimleri Enstitüsü, Gazi Üniversitesi, Ankara, Türkiye

${ }^{2}$ Matematik ve Fen Bilimleri Eğitimi Bölümü, Gazi Eğitim Fakültesi, Gazi Üniversitesi, Ankara, Türkiye
}

Sorumlu Yazar: Merve Adıüzel, adiguzelmrve@gmail.com

Makale Türü: Araştırma Makalesi

Bilgilendirme: $\mathrm{Bu}$ makale, birinci yazarın ikinci yazarın danışmanlığında tamamladığı yüksek lisans tezine dayalı olarak oluşturulmuştur.

Kaynak Gösterimi: Adıgüzel, M., \& Yılmaz, M. (2020). Biyoloji öğretmen adaylarının kavram yanılgılarının belirlenmesi ve giderilmesi üzerine bir eylem araştırması. Eğitimde Kuram ve Uygulama, 16(1), 69-82. doi: 10.17244/eku.691760

\section{Action Research on Identifying and Correcting Pre-Service Biology Teachers' Misconceptions}

\author{
Merve Adı̈üzel ${ }^{1}$, Mehmet Yılmaz ${ }^{2}$
}

1 Department of Mathematics and Science Education, Graduate School of Educational Sciences, Gazi University, Ankara, Turkey

2 Department of Mathematics and Science Education, Gazi Faculty of Education, Gazi University, Ankara, Turkey

Corresponding Author: Merve Adı̈üzel, adiguzelmrve@gmail.com

Article Type: Research Article

Acknowledgement: This article was generated based on the first author's master thesis completed under the guidance of second author.

To Cite This Article: Adıgüzel, M., \& Yılmaz, M. (2020). Biyoloji öğretmen adaylarının kavram yanılgılarının belirlenmesi ve giderilmesi üzerine bir eylem araştırması. Eğitimde Kuram ve Uygulama, 16(1), 69-82. doi: 10.17244/eku.691760 


\title{
Biyoloji Öğretmen Adaylarının Kavram Yanılgılarının Belirlenmesi ve Giderilmesi Üzerine Bir Eylem Araştırması
}

\author{
Merve Adı̈̈zzel ${ }^{1}$, Mehmet Y1lmaz ${ }^{2}$ \\ ${ }^{1}$ Matematik ve Fen Bilimleri Ĕ̆itimi Anabilim Dall, Eğitim Bilimleri Enstitüsü, Gazi Üniversitesi, Ankara, Türkiye \\ ORCID: https://orcid.org/0000-0003-2462-0231 \\ ${ }^{2}$ Matematik ve Fen Bilimleri Eğitimi Bölümü, Gazi Eğitim Fakültesi, Gazi Üniversitesi, Ankara, Türkiye \\ ORCID: https://orcid.org/0000-0001-6700-6579
}

\begin{tabular}{|c|c|}
\hline Öz & Makale Bilgisi \\
\hline $\begin{array}{l}\text { Bu araştırma, biyoloji öğretmen adaylarının Genel Biyoloji I dersi kapsamındaki konulara } \\
\text { yönelik, kavram yanılgılarını sistematik bir yönergenin takip edilerek belirlenmesi ve } \\
\text { giderilmesi amacıyla yapılmıştır. Bu amaç doğrultusunda "'Biyoloji öğretmen adaylarının } \\
\text { Genel Biyoloji I dersi kapsamındaki konulara ilişkin sahip oldukları kavram yanılgıları } \\
\text { nelerdir ve bunların giderilmesinde sistematik bir yönergenin kullanılmasının etkisi } \\
\text { nedir?", sorusuna cevap aranmıştır. Araştırmada nitel araştırma yöntemlerinden, eylem } \\
\text { araştırması yöntemi kullanılmıştır. Araştırmanın çalışma grubunu Ankara'da bir devlet } \\
\text { üniversitesinde öğrenim gören } 19 \text { biyoloji öğretmen adayı oluşturmaktadır. Araştırmanın } \\
\text { yaklaşımlarına uygun olarak planlanan veri toplama araçları ve eğitimler, tüm öğretmen } \\
\text { adaylarına aynı sürede (toplam } 16 \text { hafta) araştırmacı tarafından uygulanmıştır. Araştırma } \\
\text { sürecinde gözlem formları, birebir ve grup görüşmeleri, öğrenci günlükleri, öğrencilerin } \\
\text { not defterleri veri toplama aracı olarak kullanılmıştır. Araştırma bu araçlardan elde edilen } \\
\text { veriler üzerinden yürütülmüştür. Verilerin düzenlenmesi, özetlenmesi ve } \\
\text { yorumlanmasında ise içerik analizi yöntemi kullanılmıştır. Araştırmada, veri toplama } \\
\text { araçlarından elde edilen tüm bulgular yüzde ve frekans şeklinde verilmiştir. Biyoloji } \\
\text { öğretmen adaylarında Genel Biyoloji I dersi kapsamında aktif taşıma, bakterilerde } \\
\text { çoğalma, fermentasyon oksidatif fosforilasyon ve alel boyutlarında kavram yanılgılarının } \\
\text { olduğu belirlenmiştir. Öğretmen adaylarında mevcut olan kavram yanılgılarının sistematik } \\
\text { bir yönerge kullanılarak giderilmesine çalışılmıştır. Sürecin sonunda öğretmen }\end{array}$ & $\begin{array}{l}\text { Anahtar kelimeler: Biyoloji } \\
\text { eğitimi, Kavram yanılgıları, } \\
\text { Öğretmen adayları } \\
\text { Makale Geçmişi: } \\
\text { Geliş: } 20 \text { Şubat } 2020 \\
\text { Düzeltme: } 8 \text { Haziran } 2020 \\
\text { Kabul: } 9 \text { Haziran } 2020\end{array}$ \\
\hline
\end{tabular}




\section{Action Research on Identifying and Correcting Pre-Service Biology Teachers' Misconceptions}

\begin{tabular}{|c|c|}
\hline Abstract & Article Info \\
\hline $\begin{array}{l}\text { This study aimed to determine and overcome the misconceptions of pre-service biology } \\
\text { teachers on issues of General Biology I lesson by using a systematic instruction. To this } \\
\text { end, the study sought to answer the question 'What are misconceptions of pre-service } \\
\text { biology teachers on 1ssues of General Biology I lessons and what is the effect on these } \\
\text { misconception's overcome by using a systematic instruction. In addition, this study aimed }\end{array}$ & $\begin{array}{l}\text { Keywords: Biology education, } \\
\text { Misconceptions, Pre-service } \\
\text { teachers }\end{array}$ \\
\hline to collect data on the origins of misconceptions that pre-service biology teachers have. In & Article History: \\
\hline this study, action study method which one of the qualitative study methods, was used. The & Received: 20 February 2020 \\
\hline sample consisted of 19 preservice biology teachers studying in the Department of Biology & Revised: 8 June 2020 \\
\hline $\begin{array}{l}\text { Education of a state university in Ankara. The data collection tools and trainings planned } \\
\text { in accordance with the approaches of the study were applied to all pre-service teachers by }\end{array}$ & Accepted: 9 June 2020 \\
\hline the researcher in the same period ( 16 weeks in total). The data obtained as a result of the & Article Type: Research Article \\
\hline action study were analysed using the content analysis method. In addition, content & \\
\hline analysis method was used to organize, summarize, and interpret the data. The findings & \\
\hline were presented in frequency and percentage and examples of preservice biology teacher & \\
\hline views were quoted. It has been determined that there are misconceptions in biology pre- & \\
\hline service teachers within the scope of General Biology I course in terms of active transport, & \\
\hline bacteria growth, fermentation oxidative phosphorylation and allele dimensions. It has & \\
\hline been tried to overcome the misconceptions existing in pre-service teachers by using a & \\
\hline systematic instruction. At the end of the process, it was observed that the misconceptions & \\
\hline determined in pre-service teachers were eliminated. & \\
\hline
\end{tabular}




\section{Extended Summary}

\section{Introduction}

Complete and effective educational strategies are needed to overcome the deficiencies and negativities in traditional education, to show students a positive attitude towards the biology lesson and to train biology preservice teachers who will create a positive climate in the teaching environments. Besides education without considering the misconceptions will result graduation of prospective teachers deficiently in terms of field knowledge. This research is important in determining and overcoming the misconceptions of the pre-service biology teachers on issues of the General Biology I lesson, where the field education information. In addition, this research is important because it is a unique research independent from the research studies in the literature and it will bring a new application instruction to the literature in teacher training.

\section{Purpose of the Study}

This study aimed to determine and overcome the misconceptions of pre-service biology teachers on issues of the General Biology I lesson by using a systematic instruction. To this end, the study sought to answer the question 'What are misconceptions of pre-service biology teachers on issues of General Biology I lessons and what is the effect on these misconception's overcome by using a systematic instruction. In addition, this study aimed to collect data on the origins of misconceptions that pre-service biology teachers have'.

\section{Study Model}

\section{Method}

In this study, action study method which is one of the qualitative study methods was used.

\section{Study Group}

The study group consisted of 19 preservice biology teachers studying in the Department of Biology Education of a state university in Ankara. The data collection tools and trainings planned in accordance with the approaches of the study were applied to all pre-service teachers by the researchers in the same period (16 weeks in total).

\section{Data Collection Tool}

Qualitative data collection tools were used in the study. In this direction the questions prepared by the researchers, observation, one-to-one and group interviews, student diaries and students' notebooks were used.

\section{Data Analysis}

The data obtained as a result of the action study were analyzed through the content analysis method. In addition, content analysis method was used to organize, summarize, and interpret the data. The findings were presented in frequency and percentage and examples of preservice biology teacher views were quoted. The questions prepared by the researcher were used to determine the misconceptions of pre-service teachers. The answers given by pre-service teachers to these questions were examined by three different field experts. At the end of the review, the Reliability = Consensus / All Opinions formula put forward by Miles and Huberman (2015) was applied to determine whether there is consistency among the experts. The credibility of the study was calculated as 80 . According to Miles and Huberman (2015), data above .70 are defined as high credibility.

\section{Findings}

Within the scope of the study, an answer was sought for the question "What are misconceptions of pre-service biology teachers on issues of General Biology I lessons and what is the effect on these misconception's overcome by using a systematic instruction. In addition, this study aimed to collect data on the origins of misconceptions that pre-service biology teachers have'. The answer to the question was sought.

Systematic instruction's second, fourth, fifth and eighth steps were performed to pre-service biology teacher by researchers. Also pre-service biology teachers were asked about active transport (the ninth step of instruction). After this, $26.3 \%(f=5)$ pre-service biology teachers correctly stated the active transport. Then, the eighth, 10th, 11th, 12th and 13th steps of the instruction were followed. $89.4(\mathrm{f}=17)$ of pre-service biology teachers stated the active transport correctly.

Systematic instruction's second, fourth and fifth steps were performed to pre-service biology teacher by researchers. Also pre-service biology teachers were asked about reproduction of bacteria (the sixth step of instruction). After this, $47.3 \%(\mathrm{f}=9)$ pre-service biology teachers answered that bacteria multiplied by dividing into two. Then, the eighth, 10th and 11th steps of the instruction were followed. 100\% $(f=19)$ of pre-service biology teachers stated that bacteria multiplied by dividing into two. 
Systematic instruction's second, fourth and fifth steps were performed to pre-service biology teacher by researchers. Also pre-service biology teachers were asked about fermentation (the sixth step of instruction). After this, $42.1 \%$ ( $f=8)$ pre-service biology teachers correctly defined fermentation. Then the eighth, 10 th, $11^{\text {th }}, 12$ th and 13 th steps of the instruction were followed. $100 \%(f=19)$ of pre-service biology teachers expressed the fermentation correctly.

Systematic instruction's second, fourth and fifth steps were performed to pre-service biology teacher by researchers. Also pre-service biology teachers were asked about oxidative phosphorylation (the sixth step of instruction). After this, 89.4\% ( $\mathrm{f}=17$ ) pre-service biology teachers correctly defined oxidative phosphorylation. Then the eighth, 10th, 11th 14th and 15th steps of the instruction were followed. $100 \%$ ( $f=19)$ of pre-service biology teachers expressed the oxidative phosphorylation correctly.

Systematic instruction's second, fourth and fifth steps were performed to pre-service biology teacher by researchers. Also pre-service biology teachers were asked about allele (the sixth step of instruction). After this, $42.1 \%$ $(\mathrm{f}=8)$ pre-service biology teachers correctly defined allele as false. Then the eighth step of the instruction were followed. $100 \%(f=19)$ of pre-service biology teachers expressed the allele correctly.

\section{Discussion and Results}

In the study, it was aimed to determine and overcome the misconceptions of pre-service biology teachers on issues of the General Biology I lesson by using a systematic instruction. It was determined that all of the pre-service teachers who participated in the study had misconceptions about active transport, reproduction in bacteria, fermentation, oxidative phosphorylation and allele concepts. The reason for this misconception in teacher candidates could be the scientific errors in the textbooks and auxiliary resources and their presentation in the form of correct information to the students during the education and training process. According to Rowell, Dawson \& Harry (1990), when the information that teachers teach in the lesson is unscientific and inadequate, students may develop misconceptions. In order to avoid misconceptions among students, teachers and pre-service teachers should not have misconceptions and teachers should know possible misconceptions in their students (Gökkurt Özdemir, Bayraktar and Y1lmaz 2017). 


\section{Giriş}

Tüm eğitimcilerin ortak hedefi, öğrencilerin öğretilen bilgileri doğrudan alıp depolayabilen bireyler yetiştirmek değil; öğrendiği bilgiyi yorumlayabilen, kullanabilen ve sonunda bu bilgilerden bir ürün elde edebilen bireyler yetiştirmektir (Yıldırım \& Şimşek, 2005 s.35). Eğitim sistemlerinde; bireylere bilgilerin hap şekilde bir ilaç veya damardan yapılan bir iğne benzeri doğrudan verilip, bireylerin sorgulamadan veya bilgiyi düşünce hazinesinde yordamadan öğretilmesi gerektiğini ön gören öğretim programları başarılı olamamaktadır. Bu durum, hali hazırda okullarda yaygın bir şekilde uygulanan geleneksel öğretimin, öğrencinin pasif dinleyiciden çok öğretimin etkin bir parçası olması gerektiğini savunan bilimsel ve bilişsel teorilere zit düştüğünü göstermektedir (Kirkpatrick \& Orvis, 2002).

Duruhan (2014) geleneksel öğretim programlarının, Türkiye'nin sosyo-politik ve bilimsel yönden gelişmesinin önünde bir engel teşkil ettiğini ve bu nedenle öğretmen yetiştirme sisteminde yer almaması gerektiğini vurgulamıştır. Geleneksel eğitim modelinden farklı yeni öğretim modellerinin geliştirilmesi ve uygulanmasında öğretmenlere büyük sorumluluk düşmektedir. Öğretmenlerin yeni modellerin geliştirilmesi ve uygulanması sürecinde aktif rol alabilmesi için kendilerini çok iyi geliştirilmesi gerekir. Bu noktada da öğretmenlik mesleği Genel yeterliklerinin önemi ortaya çıkmaktadır (Yılmaz, Çimen, Karakaya \& Adıgüzel 2018).

Öğretmen yeterliği "öğretmenlerin öğretmenlik mesleğini etkili ve verimli bir biçimde yerine getirebilmek için sahip olmaları gereken bilgi, beceri ve tutumlar" olarak tanımlanmaktadır. Öğretmen yeterliklerine sahip olması gereken öğretmen adayları, alan ve alan eğitim bilgisi, öğretim ortamlarının geliştirilmesi ve iyileştirilmesi, kişisel ve mesleki bilgi düzeyinin artırılması gibi konularda donanımlı olması gerekmektedir (MEB 2017). Nitekim 2023 Eğitim Vizyon Belgesinde vurgulandığı üzere okul ekosistemin dört önemli öğesi olan öğrenci, öğretmen, veli ve okul birbirlerini etkileyen ve birbirlerinden etkilenen öğeler olması yönünden, gerekli yeterliğe sahip olmayan öğretmenler bu ekosistemi bozucu ve tahrip edici etkiye neden olacaktır. Özellikle alan ve alan eğitimi bilgisi konularında yetersiz olan öğretmenler, öğrenciler için kalıcı öğrenmeleri sağlayamayacakları gibi öğrencilerin dersle ilgili bilgi, davranış ve tutumlarını olumsuz yönde etkileyecektir. Bu noktada alan ve alan eğitimi konularında öğretmen adaylarını yetiştirecek olan eğitim fakülteleri önem arz etmektedir. Eğitim fakültelerinde uygulanan öğretim programlarıyla, öğretmen adaylarında kavram yanılgılarına neden olmamalı ve var olan kavram yanılgılarının giderilmesinde öncü rol oynamalıdır. Alanyazında yapılan çalışmalar özellikle fen derslerinde kavram yanılgılarının sayısının fazla olduğunu göstermiştir. Benzer şekilde fen dersleri içerisinde yer alan, teorik ve uygulamalı konuları bir arada bulunduran biyoloji dersi konularında öğretmen adaylarında ve bunlara bağlı olarak öğrencilerde kavram yanılgılarının olduğu çeşitli araştırmalar aracılığıyla tespit edilmiştir (Amir \& Tamir 1994, Dikmenli, Türkmen, Çardak \& Kurt, 2005, Tekkaya, Çapa \& Yılmaz, 2014 ). Ayrıca biyoloji dersine yönelik var olan kavram yanılgılarının hemen hemen hepsi Genel Biyoloji dersi kapsamındadır (Dikmenli, vd., 2005). Kavram yanılgıları göz önüne alınmadan yapılan eğitim, öğretmen adaylarının alan bilgisi yönünden eksik olarak mezun olmasına neden olacaktır. Bu araştırma, biyoloji öğretmen adaylarının, öğretmenlik mesleği yeterlik öğelerinden biri olan alan ve alan eğitimi bilgilerinin verildiği Genel Biyoloji dersi kapsamındaki kavram yanılgılarının belirlenmesi belirlenen kavram yanılgılarının giderilmesi bakımından önemlidir. Ayrıca bu araştırma alanyazındaki araştırmalardan bağımsız kendine özgü bir araştırma olduğu için ve öğretmen yetiştirmede alanyazına yeni bir uygulama yönergesi kazandıracağından önemlidir.

\section{Araştırmanın Amacı}

$\mathrm{Bu}$ araştırmada, biyoloji öğretmen adaylarının Genel Biyoloji dersi I kapsamındaki konulara yönelik sahip oldukları kavram yanılgılarının sistematik bir yönerge aracılığılla belirlenmesi ve giderilmesi amaçlanmıştır. Bu amaç doğrultusunda "Biyoloji öğretmen adaylarının Genel Biyoloji I dersi kapsamındaki konulara ilişkin sahip oldukları kavram yanılgıları nelerdir ve bunların giderilmesinde sistematik bir yönergenin kullanılmasının etkisi nedir?" sorusuna cevap aranmıştır. Ayrıca araştırmada öğretmen adaylarının sahip oldukları kavram yanılgılarının kökenlerine ilişkin veri toplanması hedeflenmiştir.

\section{Araştırmanın Modeli}

\section{Yöntem}

$\mathrm{Bu}$ araştırmada nitel araştırma yöntemlerinden, eylem araştırması yöntemi kullanılmıştır. Eylem araştırması yöntemi çeşitli kuruluşlarda yönetici, uzman, müdür ve eğitici kimlikleri olan kişilerin bizzat kendilerinin veya bir araştırmac1 yardımıyla var olan problemlerin ortaya çıkarılmasını, problemin çözümüne yönelik veri toplamayı ve analiz etmeyi içeren bir süreçtir (Yıldırım \& Şimşek 2005, s.294).

\section{Araştırmanın Çalışma Grubu}

Araştırma, Ankara'da bir devlet üniversitesinde öğrenim gören 19 biyoloji öğretmen adayı ile gerçekleştirilmiştir. Araştırmanın yaklaşımlarına uygun olarak planlanan veri toplama araçları ve eğitimler, tüm öğretmen adaylarına aynı sürede (toplam 16 hafta) araştırmacı tarafından uygulanmıştır. Araştırmanın etiği, Gazi Üniversitesi Eğitim Bilimleri 
Enstitüsü tarafından 24.04.2019 tarih ve 04 sayılı toplantısında görüşülmüş olup E.40446 sayılı yazı ile etik açıdan bir sakınca görülmemiştir.

\section{Veri Toplama Araçları}

Araştırmada nitel veri toplama araçları kullanılmıştır. Eylem araştırmalarında, araştırmanın amacının gerçekleşmesi için toplanacak veri türlerine göre nitel veri toplama araçlarının kullanılması sıkça karşılaşılan bir durumdur (Büyüköztürk, Çakmak, Akgün, Karadeniz \& Demirel, 2017). Bu doğrultuda araştırmada; araştırmacı tarafından hazırlanmış sorular, gözlem, birebir ve grup görüşmeleri, öğrenci günlükleri ve öğrencilerin not defterleri veri toplama araçlarının kullanılması planlanmıştır.

\section{Veri Toplama Süreci}

Araştırmanın uygulama süresi tüm öğrencilerle eş zamanlı olarak 16 haftada gerçekleştirilmiştir. Bu doğrultuda araştırma kapsamında öğretmen adaylarının kavram yanılgılarının belirlenmesi ve giderilmesi sürecinde uygulanan yönergenin basamakları sırasıyla şu şekildedir:

1. Adım: Öğretmen adayları ders dönemi başında derse karşı motive edilerek öğrencilerden ders dönemi boyunca günlük tutması istenir. $\mathrm{Bu}$ adım doğrultusunda öğretmen adaylarıyla tanışma gerçekleştirilmiş olup, yapılacak uygulama hakkında bilgiler verilerek bundan sonraki süreçte kendilerine düşen günlük yazma, uygulamalara katılma konularında işbirliği sağlanmıştır.

2. Adım: Öğretmen adaylarının kavram yanılgıları belirlenir. Bu adım doğrultusunda öğretmen adaylarındaki kavram yanılgıları veri toplama aracı olarak belirtilen araştırmacı tarafından hazırlanmış sorular, gözlem, birebir ve grup görüşmeleri, öğrenci günlükleri ve öğrencilerin not defterleri aracılığıyla kavram yanılgıları belirlenmiştir.

3. Adım: Öğretmen adaylarının bilimsel bilgiye güvenmesi sağlanır. Bu adım doğrultusunda dersi veren öğretim üyesinin anlatmış olduğu bilgilerin bilimsel kaynaklarda yer aldığı öğrencilere bazı bilimsel kaynaklar sınıfa getirilerek gösterilmiştir.

4. Adım: Öğretmen adaylarının yanlış bilgiye, kavram karmaşasına ve kavram yanılgısına sahip oldukları noktaları samimiyetle ifade etmelerine firsat verilir. Bu adım doğrultusunda dönem başında tespit edilen bu kavram yanılgıları ders anlatımı sırasında tekrar sorularak öğretmen adaylarından sesli ve açık bir şekilde ifade etmeleri istenmiştir

5. Adım: Tespit edilen kavram yanılgıları öğretmen adaylarına açık, anlaşılır ve ayrıntılı bir şekilde anlatılır.

6. Adım: Derslerin sonrasında öğretmen adaylarının kavram yanılgılarının giderilip giderilmediği kontrol edilir.

7. Adım: Öğrencilerin tuttukları günlükler değerlendirilerek öğrencilerle görüşmeler yapılır.

8. Adım: Kavram yanılgıları devam eden öğrencilerle grup çalışması şeklinde tartışma ortamı yaratılarak ilgili konular bilimsel kaynaklar eşliğinde tartışılır.

9. Adım: Öğretmen adaylarının kavram yanılgılarının giderilip giderilmediği kontrol edilir.

10. Adım: Kavram yanılgısı devam eden öğrencilerle video ve görsel gibi ek ders materyalleri gösterilerek konunun ayrıntılanması sağlanır.

11. Adım: Öğretmen adaylarının kavram yanılgılarının giderilip giderilmediği kontrol edilir.

12. Adım: Kavram yanılgısı devam eden öğrencilerle grup görüşmesi yapılır.

13. Adım: Öğretmen adaylarının kavram yanılgılarının giderilip giderilmediği kontrol edilir.

14. Adım: Kavram yanılgısı devam eden öğretmen adaylarıyla birebir görüşme sağlanır.

15. Adım: Öğretmen adaylarının kavram yanılgılarının giderilip giderilmediği çeşitli yollarla kontrol edilir.

Araştırma kapsamında, kavram yanılgıları kavram karmaşası ve yanlış öğrenmeleri belirleyip giderilmesi amacıyla uygulanan yönergenin 8., 9., 10., 11., 12., 13., 14., ve 15. adımdaki işlemler konunun özelliğine göre yer değiştirilebilir. Bu yönergenin hazırlanmasında bireyselleştirilmiş eğitim modeli dikkate alınmıştır. Bireyselleştirilmiş eğitim modeli her bireyin farklı öğrenme ihtiyaçlarına sahip olduğundan öğrenmenin bireysel olarak gerçekleştirilmesi gerektiğini savunan bir eğitim modelidir (Boud, 1989, s.404).

\section{Verilerin Analizi}

Eylem araştırması sonucunda elde edilen veriler içerik analizi yöntemine göre analiz edilmiştir. İçerik analizleri; elde edilen verilerin düzenlenmesi ve yorumlanmasını içeren süreçleri kapsamaktadır (Büyüköztürk vd., 2017, s.190). Araştırmada, veri toplama araçlarından elde edilen tüm bulgular yüzde ve frekans şeklinde verilmiştir. Ayrıca verilerin düzenlenmesi, özetlenmesi ve yorumlanmasında ise içerik analizi yöntemi kullanılmıştır. Öğretmen adaylarının kavram yanılgılarının belirlenmesinde dönem öncesinde araştırmacı tarafindan hazırlanan sorular kullanılmıştır. Öğretmen adaylarının bu sorulara verdikleri cevaplar üç ayrı alan uzmanı tarafından incelenmiştir. İnceleme sonunda uzmanlar arasında tutarlık olup olmadığını tespit etmek için Miles ve Huberman (2015)'in ortaya koyduğu Güvenirlik=Görüş birliği/ Tüm görüşler formülü uygulanmıştır. Çalışmanın inandırıcılı̆̆ı 1.80 olarak hesaplanmıştır. Miles ve Huberman (2015)'e göre .70'den yukarı değerlerdeki veriler inandırıcılığı yüksek olarak tanımlanmaktadır. 
Nitel araştırmalarda tutarlılığın ve inandırıcılığın belirlenmesinde araştırmada toplanan verilerin değerlendirilmesinin birden fazla uzman tarafından yapılması sıkça karşılaşılan bir durumdur (Kirk \& Miller, 1986). Araştırmada iki biyoloji alan uzmanı bir alan eğitimi uzmanı verilerin değerlendirilmesine katkı sağlamıştır. Lincon ve Gruba göre araştırmaların inandırıcılığının artması için araştırmada gözlem yapılan ortamda uzun süre etkileşim sağlanmalı, veri toplama araçları çeşitli olmalı ve veriler uzman kişiler tarafından incelemelidir (Yılmaz \& Şimşek, 2005 s.299). Araştırmada uzun süre etkileşimin sağlanması için ders dönemi boyunca her derste gözlem yapılarak öğretmen adayları hakkında notlar tutulmuştur. Bununla birlikte araştırmada dört farklı veri toplama aracı kullanılarak araştırmanın inandırıcılığı sağlanmıştır. LeCompte \& Goetz (1982)'e göre ise araştırmanın tutarlığına katkı sağlanması için araştırmada toplanan verilerin bir kısmının doğrudan sunulması önemlidir. Bu doğrultuda da araştırmada öğretmen adaylarının kavramlar hakkındaki kendi ifadelerine bulgular kısmında yer verilmiştir. Ayrıca araştırmaya katılan öğretmen adaylarının bazılarının kendi el yazılarıyla tuttukları günlükler ek kısmında sunularak araştırmanın tutarlığına katkı sağlanmıştır. Nitel araştırmalarda teyit edilebilirliğin sağlanması için araştırmanım tüm aşamaları ayrıntılı bir şekilde açılanmalıdır (LeCompte \& Goetz, 1982; Miles ve Huberman, 2015). Yapılan çalışmanın tüm aşamaları ayrıntılı bir şekilde yazılarak araştırmanın transfer edilebilirliği ve teyit edilebilirliği sağlanmaya çalışılmıştır. Böylece araştırmanın transfer edilebilirliği ve teyit edilebilirliği sağlanmıştır. Yılmaz \& Şimşek (2005)'e göre nitel araştırmalarda amaçsal örnekleme yöntemi kullanmak, araştırmanın ilerleyişine göre ek örneklem kullanmaya elverişli olması bakımından araştırmanın teyit edilebilirliğine katkı sağlamaktadır.

\section{Bulgular}

Bu bölümde, Genel Biyoloji I dersi kapsamında tespit edilen kavram yanılgıları aşağıdaki tablolarda verilmiştir. Tablolardaki bulgular öğrencilerin günlüklerinden, muhtemel kavram yanılgılarını belirlemeye yönelik yapılan testlere verdiği cevaplardan, sınıf içi gözlemlerden ve öğrencilerle yapılan görüşmelerden elde edilmiştir.

Araştırma kapsamında "Biyoloji öğretmen adaylarının Genel Biyoloji I dersi konularına yönelik kavram yanılgıları var mıdır?" sorusuna yanıt aranmış ve elde edilen veriler Tablo 1'de sunulmuştur.

Tablo 1. Genel Biyoloji I dersi kapsamında tespit edilen kavram yanılgılarına ait bulgular

\begin{tabular}{|c|c|c|c|}
\hline Temalar & f & $\%$ & Örnek öğrenci görüşleri \\
\hline Aktif taşıma & 9 & 100 & $\begin{array}{l}\text { Ö7: Aktif taşıma enerji harcayarak büyük moleküllerin hücre zarından geçmesini sağlar. } \\
\text { Ö12: Büyük moleküllerin az yoğun ortamdan çok yoğun ortama geçişini sağlayan yönteme aktif taşıma denir } \\
\text { Ö15: Protein, nişasta gibi büyük moleküller aktif taşıma yoluyla hücre zarından geçerler. } \\
\text { Ö17: Büyük moleküllerin hücre içinden geçmesi aktif taşımayla olur. } \\
\text { Ö18: Difüzyon küçük maddelerin geçişini sağlarken aktif taşıma büyük maddelerin hücre zarından geçmesini } \\
\text { sağlar. }\end{array}$ \\
\hline $\begin{array}{l}\text { Bakterilerde } \\
\text { çoğalma }\end{array}$ & 9 & 100 & $\begin{array}{l}\text { Ö7: Bakteriler, eşeyli ve eşeysiz çoğalır. } \\
\text { Ö8: Bakteriler tomurcuklanma ve mitozla ürerler. } \\
\text { Ö11: Konjugasyon, partenogenez ve mitoz bölünme ile bakteriler çoğalabilir. } \\
\text { Ö15: Fermentasyon ve translasyonla ürerler. } \\
\text { Ö19: Bakteriler mayoz, mitoz ve konjugasyonla ürer. }\end{array}$ \\
\hline Fermentasyon & 9 & 100 & $\begin{array}{l}\text { Ö4: Fermentasyon oksijensiz solunumun diğer adidır. } \\
\text { Ö7: Oksijensiz solunumdur. } \\
\text { Ö13: Solunum oksijenli ve oksijensiz (fermentasyon) solunum olarak ikiye ayrilır. } \\
\text { Ö18: Bazı canlılar oksijen bulunmayan ortamda oksijensiz solunum yapar buna fermentasyon denir. } \\
\text { Ö19: Oksijensiz solunum laktik asit fermentasyonu ve etil alkol fermentasyonu olarak ikiye ayr1lır. }\end{array}$ \\
\hline $\begin{array}{c}\text { Oksitatif } \\
\text { fosforilasyon }\end{array}$ & 9 & 100 & $\begin{array}{l}\text { Ô3: Oksijenli solunum yapan canlllar substrat düzeyinde ve oksidatif düzeyde fosforilasyon yaparken oksijensiz } \\
\text { solunum yapan canlılar sadece substrat düzeyinde fosforilasyon yapar. } \\
\text { Ö5: Tüm canlılar substrat düzeyinde fosforilasyon yapar. Oksijenli solunum yapan canlılar ayrıca oksidatif } \\
\text { fosforilasyon yapar. } \\
\text { Ö8: Glikoliz bütün canlıların solunumunda ortak olduğundan tüm canlılar substrat düzeyinde fosforilasyon } \\
\text { yaparken tüm canlılar oksijen kullanmadığ i için oksidatif fosforilasyon yapamaz. } \\
\text { Ö14: Sadece ETS de son elektron alıcısı oksijen molekülü olan canlllar oksidatif fosforilasyon yapar. }\end{array}$ \\
\hline Alel & 9 & 100 & $\begin{array}{l}\text { Ö2: Bezelyelerin buruşuk ve düz olmasında iki tane gen görev yapar. } \\
\text { Ö5: Bazı alel genler diğer bazı alel genlere baskın olabilir. } \\
\text { Ö11: Genler birbiri üzerine eksik baskın olunca iki gende de etkisini göstermez. } \\
\text { Ö15: Eş baskın genlere örnek olarak A ve B kan grupları verilebilir. } \\
\text { Ö18: Alel genleri baskın, çekinik, eş baskın ve eksik baskın olarak dörde ayırabiliriz. }\end{array}$ \\
\hline
\end{tabular}

Tablo 1'deki veriler incelendiğinde araştırmaya katılan öğretmen adaylarının \%100'ünde ( $\mathrm{f}=19)$ aktif taşıma, bakterilerde çoğalma fermentasyon oksidatif fosforilasyon ve alel konularında kavram yanılgılarına sahip olduğu belirlenmiştir.

Araştırma kapsamında 'Biyoloji öğretmen adaylarının Genel Biyoloji I dersi kapsamındaki konulara yönelik kavram yanılgılarının giderilmesinde uygulanan yönergenin etkisi nedir? sorusuna cevap aranmış elde edilen bulgular aşağıda verilmiştir. 
Aktif Taşıma ile İlgili Kavram Yanılgılarının Uygulanan Yönergeyle Giderilmesine Yönelik Bulgular

Araştırma kapsamında öğretmen adayları aktif taşıma kavramı ile ilgili yanlış bilgiler vermişlerdir (Tablo 1). Ancak alanyazın incelendiğinde aktif taşıma; konsantrasyon gradiyentinin zıt yönünde taşıyıcı proteinler yardımıyla hücre zarından geçebilecek boyuttaki moleküllerin enerji harcayarak geçişi (Reece, Urry, Cain, Wasserman, Minorsky \& Jackson, 2013: s.135, Sadava, Hillis, Heller \& Berenbaum, 2014: s.120) şeklinde ifade edilmektedir.

Öğretmen adaylarındaki bu kavram yanılgıları araştırmacı tarafından hazırlanmış olan kavram yanılgılarını saptamaya yönelik sorular ile dönem başında belirlenmiştir. (Yönergenin ikinci adımı). Dönem başında tespit edilen bu kavram yanılgıları ders anlatımı sırasında tekrar sorularak öğretmen adaylarından sesli ve açık bir şekilde ifade etmeleri istenmiştir (Yönergenin dördüncü adımı). Sonrasında aktif taşıma ile ilgili bilgilerin doğru ifadesi açık, net ve ayrıntılı bir şekilde anlatılmıştır (Yönergenin beşinci adımı). Dersten bir hafta sonra öğretmen adaylarına aktif taşımanın ne olduğu sorulmuştur (Yönergenin altıncı adımı). Bu etkinlik sonrasında öğretmen adaylarının \%100'ü ( $\mathrm{f}=19$ ) aktif taşımayı yanlış ve eksik ifade etmişlerdir. Öğretmen adaylarıyla ders saatleri dışında tekrardan bir araya gelinerek bilimsel kaynaklar eşliğinde konu tekrardan anlatılarak tartışılmıştır. Bu sayede öğretmen adaylarının kavramlarla ilgili düşüncelerini açığa vurulmaları ve doğru bilgiyi mantık çerçevesinde zihinlerine yerleştirmeleri sağlanmıştır. (Yönergenin sekizinci adımı). Bu etkinlikten bir hafta sonra öğretmen adaylarına aktif taşımanın ne olduğu tekrar sorulduğunda adayların \%26.3'ü (f=5) aktif taşımayı doğru bir şekilde ifade etmişlerdir. (Yönergenin dokuzuncu adımı). Konunun iyice anlaşılması açısından öğretmen adaylarıyla tekrardan bir araya gelinerek videoanimasyon gösterileri sunulara konu tekrardan anlatılmıştır Teker teker tüm basamaklar yeniden ele alınmıştır (Yönergenin 10. adımı). Bu etkinlik sonrasında öğretmen adaylarına aktif taşımanın ne olduğu tekrar sorulmuştur (Yönergenin 11. adımı). Öğretmen adaylarının \%63.1'i ( $\mathrm{f}=12$ ) aktif taşımayı doğru bir şekilde ifade etmişlerdir. Kavram yanılgıları devam eden öğretmen adaylarıyla tekrardan bir araya gelinerek aktif taşıma kavramı ve diğer hücre zarı taşınmaları karşılaştırılarak anlatılmış konuyla ilgili öğretmen adaylarının soruları cevaplanmıştır (Yönergenin 12. adımı). Bu etkinlik sonrasında öğretmen adaylarıyla bir araya gelinmiş aktif taşımanın ne olduğu tekrar sorulmuştur (Yönergenin 13. adımı). Öğretmen adaylarının 89.4'ü (f=17) aktif taşımayı doğru bir şekilde ifade etmişlerdir.

Ayrıca Öğretmen adayları tuttukları günlüklerde aktif taşıma ile ilgili kavram yanılgılarının kökenini açıklamışlardır:

Ö8: 9. Sinıfta aktif taşıma konusunu işlerken tam anlayamamıştım ve şimdi de öğrenmekte ve anlamak da zorluk çektim.

Ö17: Lisede öğrenirken aktif taşımanın enerji ile ilgili olduğunu ayrıca enerji ve zardan geçemeyecek büyük maddeler varsa aktif taşımadır şeklinde kodladığımı hatırlyyorum. Kavram soyut olduğu için sadece ezber yaparak öğrenmeye çalışlyordum. Şu an öğrenirken ezber yapmadım ve aktif taşıma olayının mantı̆̆ın iyice kavradı̆̆ımı düşünüyorum.

Öğretmen adaylarının bazıları tuttukları günlüklerde lisede almış oldukları eğitim sırasında hücrede madde alış-verişini iyi anlamadıklarını belirtmişlerdir. Ayrıca bazı öğrenciler de günlüklerinde aktif taşımayı öğrenme sürecinde zorlandıklarını ve soyut bir konu olduğundan zihinlerinde canlandırmakta zorluk çektiklerini söylemişlerdir.

\section{Bakterilerde Üreme ile İlgili Kavram Yanılgılarının Uygulanan Yönergeyle Giderilmesine Yönelik Bulgular}

Araştırma kapsamında öğretmen adayları bakterilerin üreme şekillerini Genel olarak mitoz, konjugasyon ve mayoz şekillerinde olabileceğini ifade etmiştir (Tablo 1). Ancak alanyazın incelendiğinde bakterilerin üreme şeklinin ikiye bölünme olarak ifade edildiği görülmektedir (Madigan, Martinko \& Parker, 2010, s.144; Reece, vd., 2013, s.236).

Öğretmen adaylarındaki bu kavram yanılgıları araştırmacı tarafından hazırlanmış olan kavram yanılgılarını saptamaya yönelik sorular ile dönem başında belirlenmiştir. (Yönergenin ikinci adımı). Dönem başında tespit edilen bu kavram yanılgıları ders anlatımı sırasında tekrar sorularak öğretmen adaylarından sesli ve açık bir şekilde ifade etmeleri istenmiştir (Yönergenin dördüncü adımı). Sonrasında bakterilerin çoğalmasıyla ilgili bilgilerin doğru ifadesi açık, net ve ayrıntılı bir şekilde anlatılmıştır (Yönergenin beşinci adımı). Dersten bir hafta sonra öğretmen adaylarına bakterilerin üreme şekli sorulmuştur (Yönergenin altıncı adımı). Bu etkinlik sonrasında öğretmen adaylarının \%47.3’i $(\mathrm{f}=9)$ bakterilerin ikiye bölünerek çoğaldığını ifade etmiştir. Öğretmen adaylarıyla ders sonrasında bir araya gelinerek konu bilimsel kaynaklar eşliğinde tekrar anlatılarak tartışılmıştır (Yönergenin sekizinci adımı). Bir sonraki hafta tekrar sorulduğunda öğretmen adaylarının \%78.9'ü ( $\mathrm{f}=15)$ bakterilerin ikiye bölünerek çoğaldığını ifade etmişlerdir (Yönergenin dokuzuncu adımı). Kavram yanılgısı devam eden öğretmen adaylarıyla bir araya gelinerek bilimsel kaynaklardan elde edilmiş bakterilerin bölünme sürecini içeren video gösterisi izletilmiştir (Yönergenin 10. adımı). Ardından konuyla ilgili öğretmen adaylarının soruları cevaplandırılarak etkinlik sona erdirilmiştir. Bu etkinlik sonrasında öğretmen adaylarına bakterilerin nasıl ürediği tekrar sorulmuştur (Yönergenin 11. adımı). Öğretmen adaylarının \%100’ü (f=19) bakterilerin ikiye bölünerek çoğaldığını belirtmişlerdir

Ayrıca öğretmen adaylarının bazıları tuttukları günlüklerde lise eğitimi ve üniversiteye hazırlık sürecinde bakterilerin mitozla, eşeysiz, konjugasyonla ve eşeyli bir şekilde ürediklerini öğretmenlerinden ve kitaplarından öğrendiklerini belirtmişlerdir. 
Ö4: Lisedeki bilgilerimden hatırladığım kadarıyla bakteriler konjugasyonla eşeyli olarak çoğalıyor.

Ö7: Bakteriler eşeyli ve eşeysiz olarak çoğalabildiğini üniversite sınavına hazırlanırken aldığım kitaplardan ögrenmişstim.

\section{Fermentasyon ile İlgili Kavram Yanılgılarının Uygulanan Yönergeyle Giderilmesine Yönelik Bulgular}

Araştırma kapsamında öğretmen adayları fermentasyonu oksijensiz solunum şeklinde tanımlamışlardır (Tablo 1). Ancak alanyazın incelendiğinde fermentasyonun oksijensiz solunumun bir çeşidi olmadığı; fermentasyon, oksijenli ve oksijensiz solunumun üç ayrı süreç olduğu bilgisi yer almaktadır (Nelson, Lehninger \& Cox, 2008, s. 527; Reece vd., 2013, s.164-178, Sadava vd., 2014, s.170-181).

Öğretmen adaylarındaki bu kavram yanılgıları araştırmacı tarafından hazırlanmış olan kavram yanılgılarını saptamaya yönelik sorular ile dönem başında belirlenmiştir (Yönergenin ikinci adımı). Dönem başında tespit edilen bu kavram yanılgıları ders anlatımı sırasında tekrar sorularak öğretmen adaylarından sesli ve açık bir şekilde ifade etmeleri istenmiştir (Yönergenin dördüncü adımı). Sonrasında fermentasyon ile ilgili bilgilerin doğru ifadesi açık, net ve ayrıntılı bir şekilde anlatılmıştır (Yönergenin beşinci adımı). Dersten bir hafta sonra öğretmen adaylarına fermentasyonun ne olduğu sorulmuştur (Yönergenin altıncı adımı). Bu etkinlik sonrasında öğretmen adaylarının \%42.1 ' $\mathrm{i}(\mathrm{f}=8)$ fermentasyonu doğru bir şekilde tanımlamışlardır. Öğretmen adaylarıyla ders saati dışında bir araya gelinerek bilimsel kaynaklar eşliğinde konu yeniden anlatılarak tartışılmıştır (Yönergenin sekizinci adımı). Bu etkinlikten bir hafta sonra öğretmen adaylarına fermentasyonun ne olduğu tekrar sorulmuştur (Yönergenin dokuzuncu adımı). Öğretmen adaylarının \%68.4'ü ( $\mathrm{f}=13)$ fermentasyonu doğru bir şekilde ifade etmişlerdir. Konunun iyice anlaşılması açısından öğretmen adaylarıyla tekrardan bir araya gelinerek video-animasyon gösterileri sunularak tüm basamaklar irdelenmiştir (Yönergenin 10. adımı). Bu etkinlikten bir hafta sonra öğretmen adaylarına fermentasyonun ne olduğu tekrar sorulmuştur (Yönergenin 11. adımı). Kavram yanılgıları devam eden öğretmen adaylarıyla tekrardan bir araya gelinerek fermentasyonun ne olduğu anlatılmış ve konuyla ilgili soruları cevaplanmıştır (Yönergenin 12. adımı). Bu etkinlik sonrasında öğretmen adaylarıyla bir araya gelinerek fermentasyonun ne olduğu tekrar sorulmuştur (Yönergenin 13. adımı). Öğretmen adaylarının \%100’ü ( $\mathrm{f}=19)$ fermentasyon doğru bir şekilde ifade etmişlerdir.

Ayrıca öğretmen adaylarının bazıları tuttukları günlüklerde lisede almış oldukları eğitim sırasında fermentasyonu oksijensiz solunum olarak öğrendiklerini belirtmişlerdir:

Ö2: Lisede Oksijensiz solunum =fermentasyon şeklinde ögrendim.

Ö9: Lisede hocalarımız Oksijensiz Solunum (Fermentasyon) şeklinde yazdırarak bize ikisinin aynı olduğunu anlattı.

Oksidatif Fosforilasyon ile İlgili Kavram Yanılgılarının Uygulanan Yönergeyle Giderilmesine Yönelik Bulgular Araştırma kapsamında öğretmen adayları oksidatif fosforilasyonu oksijenli solunumda ATP sentezlenmesi için kullanılan yollardan biri olduğunu ifade etmişlerdir (Tablo 1). Ancak alanyazın incelendiğinde oksidatif fosforilasyonun elektron taşıma sisteminde ADP'den ATP sentezlenmesi şeklinde ifade edilmektedir. Ayrıca alanyazında oksijenli ve oksijensiz solunum yapan canlıların elektron taşıma basamağını kullandıklarından her iki canlı grubundaki canlıların oksidatif fosforilasyon yaptığı belirtilmektedir (Nelson, Lehninger, \& Cox, 2008 s.659, Reece vd, 2013, s.168, Sadava vd., 2014, s.178).

Öğretmen adaylarındaki bu kavram yanılgıları araştırmacı tarafından hazırlanmış olan kavram yanılgılarını saptamaya yönelik sorular ile dönem başında belirlenmiştir. (Yönergenin ikinci adımı). Dönem başında tespit edilen bu kavram yanılgıları ders anlatımı sırasında tekrar sorularak öğretmen adaylarından sesli ve açık bir şekilde ifade etmeleri istenmiştir (Yönergenin dördüncü adımı). Sonrasında oksidatif fosforilasyon hakkındaki bilgilerin doğru ifadesi açık, net ve ayrıntılı bir şekilde anlatılmıştır (Yönergenin beşinci adımı). Dersten bir hafta sonra öğretmen adaylarına oksidatif fosforilasyonun ne olduğu ve hangi süreçlerde görüldüğü sorulmuştur (Yönergenin altıncı adımı). $\mathrm{Bu}$ etkinlik sonrasında öğretmen adaylarının \%89,4'ü (f=17) oksidatif fosforilasyonu sadece oksijenli solunumda ATP sentezlenmesi için kullanılan yollardan biri olarak tanımlamışlardır. Öğretmen adaylarıyla ders saati dışında bir araya gelinerek bilimsel kaynaklar eşliğinde konu tekrardan anlatılarak tartışılmıştır (Yönergenin sekizinci adımı). Bu etkinlikten bir hafta sonra öğretmen adaylarına oksidatif fosforilasyonun ne olduğu ve hangi metabolik süreçlerde görüldüğü tekrar sorulmuştur (Yönergenin dokuzuncu adımı). Öğretmen adaylarının \%52,6's1 (f=10) oksidatif fosforilasyonu sadece oksijenli solunumda ATP sentezlenmesi için kullanılan yollardan bir olarak tanımlamışlardır. Konunun iyice anlaşılması açısından öğretmen adaylarıyla tekrardan bir araya gelinerek video-animasyon gösterileri sunularak konu tekrardan anlatılarak tüm basamaklar irdelenmiştir (Yönergenin 10. adımı). Bu etkinlik sonrasında öğretmen adaylarına oksidatif fosforilasyonun ne olduğu ve hangi süreçlerde görüldüğü tekrar sorulmuştur (Yönergenin 11. adımı). Öğretmen adaylarının \%78,9'u ( $\mathrm{f}=15)$ oksidatif fosforilasyonu doğru bir şekilde tanımlamışlardır. Kavram yanılgısı devam eden dört öğrenci ile birebir görüşme yapılarak ek ders materyalleri (farklı bilimsel kaynaklar ve oksidatif fosforilasyonun dayandığı elektron taşıma sistemine ait görsel ve çizimler) ile kavram yanılgıları giderilmeye çalışılmıştır. (Yönergenin 14. adım) Bir hafta sonra tüm öğretmen adaylarına oksidatif fosforilasyonun ne olduğu ve hangi süreçlerde görüldüğü sorulmuştur (Yönergenin 15. adımı). Öğretmen adaylarının $\% 100$ 'ü (f=19) oksidatif fosforilasyonu doğru bir şekilde tanımlamışlardır. 
Öğretmen adaylarının günlükleri incelendiğinde, öğretmen adaylarının bazıları lisede almış oldukları eğitim ve üniversiteye hazırlık sürecinde oksidatif fosforilasyonu oksijenle bağdaştırarak sadece oksijenli solunumda görüldüğü kavram yanılgısını yapılan uygulamalar sayesinde giderdiklerini belirtmişlerdir:

Ö5: Lisede ögrretmenimiz oksijen varsa oksidatif fosforilasyon vardır demişti ve bende o şekilde kodlamıştım.

Ö16:Oksi-datif fosforilasyonun oksi kelimesinin oksijenden geldiğini öğrenmiştim ama şimdi indirgenme ve yükseltgenme tepkileriyle alakalı olduğunu ve oksijene bağlı olmaksızın Ets süreçleriyle ile alakalı olduğunu uygulamalar sayesinde kavradım.

\section{Alel ile İlgili Kavram Yanılgılarının Uygulanan Yönergeyle Giderilmesine Yönelik Bulgular}

Araştırma kapsamında öğretmen adayları alel kavramını, gen kavramı yerine kullanmışlardır. Bununla birlikte öğretmen adayları alel gen olarak bilimsel karşılığı olmayan ifadelere yer vermişlerdir. (Tablo 1). Genlerin alternatif şekilleri olan alelleri, kalıtılan karakterdeki varyasyonlardan sorumludur Bununla birlikte alanyazında alellerin aynı genin farklı formları olduğu bilgisi yer almaktadır (Klug \& Cummings, 2003, s.4, Brooker, Widmaier, Graham \& Stiling 2012, s.23; Reece vd., 2013, s.265; Sadava vd., 2014, s.222; Simon, Dickey, Hogan \& Reece, 2017, s.148; Mader \& Windelspecht, 2018, s.147).

Öğretmen adaylarındaki bu kavram yanılgıları araştırmacı tarafından hazırlanmış olan kavram yanılgılarını saptamaya yönelik sorular ile dönem başında belirlenmiştir. (Yönergenin ikinci adımı). Dönem başında tespit edilen bu kavram yanılgıları ders anlatımı sırasında tekrar sorularak öğretmen adaylarından sesli ve açık bir şekilde ifade etmeleri istenmiştir (Yönergenin dördüncü adımı). Sonrasında alel ve gen ile ilgili bilginin doğru ifadesi açık, net ve ayrıntılı bir şekilde anlatılmışıı (Yönergenin beşinci adımı). Dersten bir hafta sonra öğretmen adaylarına alelin ne olduğu sorulmuştur (Yönergenin altıncı adımı).. Öğretmen adaylarının \%42,1’i (f=8) aleli yanlış olarak ifade etmişlerdir. Öğretmen adaylarıyla ders sonrasında bir araya gelinerek konu bilimsel kaynaklar ve genetik problemleri üzerinde tartışılarak anlatılmıştır (Yönergenin sekizinci adımı). Bu etkinlik sonrasında öğretmen adaylaruna alelin ne olduğu sorulmuştur (Yönergenin dokuzuncu adımı). Öğretmen adaylarının \%100’ü (f=19) aleli doğru bir şekilde tanımlamıştır.

Öğretmen adaylarının bazıları günlüklerinde, lisede almış oldukları eğitim ve üniversiteye hazırlık sürecinde aleli, gen ile eşdeğer olarak bildiklerini, bu yanılgılarını da yapılan uygulamalar sayesinde giderdiklerini belirtmişlerdir:

Ö7: 10. sinıfta alel gen olarak ögrendiğim bu kavramı şimdi daha iyi anlayarak ayırt edebiliyorum.

Ö12: Üniversite slnavinı hazırlanırken kitaplardan alel gen olarak öğrenmiştim.

Araştırmanın tamamlanmasından altı ay sonra giderilen bu kavram yanılgılarının biyoloji öğretmen adaylarındaki kalıcılığına bakılmıştır. Bu doğrultuda biyoloji öğretmen adaylarına bu kavramlar tekrar sorulmuştur. Araştırmaya katılan biyoloji öğretmen adaylarının \%100'ünde ( $\mathrm{f}=19)$ aktif taşıma, bakterilerde çoğalma fermentasyon, oksidatif fosforilasyon ve alel kavramlarını doğru bir şekilde ifade etmişlerdir.

\section{Sonuç ve Tartışma}

Bu bölümde araştırma kapsamında elde edilen bulgular alanyazınına göre tartışılarak yorumlanmıştır. Araştırmada, biyoloji öğretmen adaylarının Genel Biyoloji dersi I kapsamındaki konulara yönelik kavram yanılgılarının, kavram karmaşalarının ve yanlış öğrenmelerinin sistematik bir yönergenin takip edilerek belirlenmesi ve giderilmesi amaçlanmıştır.

Araştırmaya katılan öğretmen adaylarının tamamında aktif taşıma, bakterilerde üreme, fermentasyon, oksidatif fosforilasyon ve alel boyutları ile ilgili kavram yanılgılarına sahip olduğu belirlenmiştir. Öğretmen adaylarında bu kavram yanılgılarının oluşmasının; ders kitaplarında ve yardımcı kaynaklarda yer alan bilimsel hatalar ve bunların eğitim-öğretim sürecinde öğretmenler tarafından öğrencilere doğru bilgiler şeklinde sunuluyor olmasından kaynaklandığg düşünülmektedir.

Nitekim Gündüz, Yılmaz, Çimen ve Şen (2017) MEB ortaöğretim 11. sınıf biyoloji ders kitabını bilimsel açıdan inceledikleri çalışmalarında biyoloji ders kitabındaki birçok bilimsel hatayı belirlemişler ve bu hataların kavram yanılgılarına yol açtıklarını ifade etmişlerdir. Ayrıca yaptıkları çalışmada MEB biyoloji ders kitabında konjugasyonun bakterilerde ve paramesyumlarda üreme şekli olarak verildiğini hakkında hatalı ifadelere yer verildiğini belirtmişlerdir. 2016 yılında 10. sınıf olan ortaöğretim öğrencilerin 2018-2019 eğitim-öğretim y1lında üniversite birinci sınıfta öğrenim gören öğretmen adayları olarak karşımıza kavram yanılgıları ile geldiği görülmektedir. Bu bağlamda araştırmada elde edilen bulgular, Gündüz, Yılmaz ve Çimen (2016) tarafından yapılan araştırmanın sonuçlarını desteklemektedir. Ayrıca Rowell, Dawson \& Harry (1990)'e göre öğretmenlerin derste öğrettikleri bilgiler bilimsellikten uzak ve yetersiz olduğunda, öğrencilerinde kavram yanılgıları meydana gelmektedir. Öğrencilerde kavram yanılgılarının oluşmaması için öğretmenlerde ve öğretmen adaylarında kavram yanılgılarının bulunmaması ve öğretmenlerin de öğrencilerindeki muhtemel kavram yanılgılarını önceden bilmeleri gereklidir (Gökkurt Özdemir, Bayraktar \& Yılmaz 2017). 
Araştırmada tespit edilen kavram yanılgılarına paralel olarak Harman (2014)'ün hücre zarından madde taşınımları ile ilgili kavram yanılgılarını tespit etmeye yönelik çalışmasında, fen bilgisi öğretmen adaylarının aktif taşıma sırasında ortamlar arası derişim farkı ve enerji kullanımı konularında kavram yanılgılarına sahip oldukları tespit edilmiştir. Vitharana (2015) ise bitkilerdeki taşıma konusundaki kavram yanılgılarını belirlemeye yönelik yaptığı çalışmada 10. sınıf öğrencilerinin difüzyon ve aktif taşıma konularında kavram yanılgılarına sahip olduğunu belirlemiştir. Ayrıca Yılmaz, Gündüz, Diken ve Çimen'in (2017) 8. sınıf fen bilgisi kitabını bilimsel olarak inceledikleri çalışmalarında fen bilgisi ders kitabında solunum şekillerini ikiye ayırarak oksijenli ve oksijensiz solunum şeklinde ifade edildiğini ve bu ifadenin bilimsel olarak hatalı olduğunu belirtmişlerdir. Gündüz, Yılmaz, Çimen ve Şen (2017)'in 11. sınıf ders kitabının bilimsel olarak incelenmesiyle ilgili yaptıkları çalışmada ise, biyoloji ders kitabında oksijensiz solunum tanımları yerine fermentasyon tanımlarının yapıldığını, oksijensiz solunum diye belirtilen tüm süreçlerin fermentasyona ait olduğunu, oksijensiz solunum ve fermentasyon kavramlarının birbiri yerine kullanıldığını, bu kullanımın bilimsel olarak hatalı ve oksijensiz solunum ile fermentasyonun ayrı kavramlar olduklarını belirtmişlerdir. Ayrıca Kırbaşlar, Barış \& Ünal (2009)'un fen bilgisi öğretmen adaylarındaki fermentasyon ile ilgili yanlış öğrenmelerinin araştırılması ile ilgili çalışmada ilk ve ortaokul düzeylerinde fermentasyon=oksijensiz solunum olarak verildiğinden öğretmen adaylarının fermentasyonla ilgili doğru bilgileri öğrenmekte zorlandıklarını belirtmişlerdir. Yürük ve Çakır (2000), lise öğrencileri ile yaptıkları çalışmada öğrencilerin fermentasyon konusuyla ilgili kavram yanılgılarına sahip olduklarını tespit etmişlerdir. Ancak solunumu oksijenli ve oksijensiz solunum şeklinde inceleyerek fermentasyonu ayrı bir süreç olarak belirtmemişlerdir. Bu ayrımın yapılmaması bilimsel olarak hatalıdır. Alel konusundaki kavram yanılgılarına paralel olarak, Gündüz, Yılmaz ve Çimen'in (2016) 10.sınıf biyoloji ders kitabının bilimsel olarak incelenmesiyle ilgili yaptıkları çalışmada, biyoloji ders kitabında alel kavramı yerine gen kavramının kullanıldığını ve bu durumun kavram yanılgılarına yol açabileceğini belirtmişlerdir.

Tekkaya, Çapa ve Yılmaz'ın (2000) biyoloji öğretmen adaylarıyla yaptıkları çalışmada biyoloji öğretmen adaylarında genetik konusuna ait gen ve alel gibi bazı kavramlara yönelik kavram yanılgılarının olduğunu tespit etmişlerdir. Pashley (1994)'ün gen ve alel kavramlarının öğretimi için yaptığı kromozom modeliyle genetik konusuna yönelik öğrencilerdeki kavram yanılgılarını giderilebileceğini göstermiştir. Ayrıca öğretmenlerin öğrencilerdeki kavram yanılgılarını önceden tespit etmesinin öğrencilerin akademik başarılarını arttırdığını bildirmiştir. Tatar \& Cansüngü Koray (2005)'in ilköğretim son sınıf öğrencileriyle yaptıkları çalışmada, öğrencilerin genetik konusuna ait gen, DNA ve kromozom kavramlarıyla ilgili yanılgılarının olduğunu belirlemişlerdir. Ayrıca çalışmada, öğrencilerin büyük bir çoğunluğunun genetik kod kavramını bilmediklerini tespit etmişlerdir. Etobro \& Banjoko (2017) 120 biyoloji öğretmen adayı ile yaptığı çalışmada ise öğretmen adaylarının \%75,1'inde genetik konusuyla ilgili kavram yanılgıları olduğunu bulmuşlardır. Bu sonuçlar araştırmanın bulgularını desteklemektedir.

Araştırmada kavram yanılgıların giderilme sürecinde tartışma ortamlarının oluşturulup, video animasyon gibi ek öğretim materyallerinden yararlanılmıştır. Ayrıca öğretmen adaylarıyla birebir ve grup görüşmeleri yapılmıştır. Tüm bu süreçlerin kavram yanılgılarını gidermede etkili olduğu görülmüştür. Nitekim Riche (2000)'e göre kavram yanılgılarının giderilmesinde tartışma ortamları oluşturulması kavram yanılgılarının giderilmesindeki en etkili yöntemlerden biridir. Rowell, Dawson, Harry (1990)'e göre öğrenciler bilimsel bilginin doğruluğu konusunda öğretici veya arkadaşlarıyla tartışmaya girdiğinde bilginin dayanağını keşfederek tartışma sonunda hangi bilginin beyninde kalacağına karar verir. Böylece sahip olduğu kavram yanılgısını kalıcı olarak bilimsel bilginin doğru ifadesiyle değiştirir. Tartışma ortamları ile birlikte öğrenciler bilgilerini sorgulayarak kendi bilgilerinde düzenlemeye gitmektedir (Tertemiz, 2011 s.25). Brown (1995) göre öğretilen kavramların ezberden çıkarılarak mantıksal bir çerçeve oturtulmasında en etkili faktörün görsel, film, video ve somut materyaller olduğunu ileri sürmüştür. Kaya (2010) yaptığı çalışmada kavram yanılgılarının animasyon ve video gibi görsel ve işitsel ders materyalleri kullanarak giderilebileceği sonucuna ulaşmıştır. Özellikle kavramları görsel hale getirmek, kavram yanılgılarının hem belirlenmesi hem de giderilmesinde oldukça önemlidir (Tekkaya, Çapa \& Yılmaz, 2000). Mulholland \& Ginns (2008) yaptıkları çalışmada tartışma ortamlarının oluşturulması ve öğrencilerle görüşme yapılmasının alternatif kavramların giderilmesinde etkili olduğunu belirtmişlerdir. Nitekim yanlış öğrenmelerin kavram yanılgılarından farklı olarak değişmeye direnç göstermezler (Monfort, Brown \& Findley, 2007). Yanlış öğrenmeler için giderilmesi için öğrencinin yanlış ifadenin doğrusuyla mantık çerçevesinde karşılaşmasına bağlıdır (Fisher, 1985). Bu görüşler araştırmanın bulgularını desteklemektedir.

\section{Öneriler}

$\mathrm{Bu}$ araştırma sonuçlarına göre biyoloji öğretmen adaylarında temel kavramlara ilişkin çok sayıda kavram yanılgısı, kavram karmaşası ve yanlış öğrenmelerin olduğu belirlenmiştir. Alanyazın bulguları da bu durumu açıkça desteklemektedir. Bu nedenle öğretmen ve öğretim elemanlarının yürütecekleri biyoloji alan derslerinde, planlamaları ve içerikleri bunlara dikkat ederek oluşturmaları çok yararlı olacaktır.

MEB Fen Bilimleri ve Biyoloji ders kitaplarında yer alan ve alt sinıflardan itibaren üst sinıflara kadar tekrarlanan bilimsel hataların öğrencilerde çeşitli yanılgılara neden olduğu anlaşılmıştır. Bu nedenle kitapların yazımı 
ve seçilmesi konusunda yetkili olan Talim Terbiye Kurulu Başkanlığının gerekli önlemleri alması, mevcut kitapların yenilenmesi ve yeni kitapların yazımı sürecinde paydaşları bilgilendirmesinin çok yararlı olacağı düşünülmektedir.

$\mathrm{Bu}$ araştırmada öğretmen adaylarının her birinin aynı veya farklı konulardaki kavramlar hakkında yanılgılara, yanlış öğrenmelere ve karmaşalara sahip olduğu belirlenmiştir. Bu tür yanılgılara sahip olan adayların bu yanılgılarının bir kez üzerinde durulduğunda giderilemediği anlaşılmıştır. Bu yanılgıları belirleyen öğretmen ve öğretim elemanlarının öğrencilerinin yanılgılarından kurtulabilmesi için bireysel öğretim programları uygulamalarının tam öğrenmenin gerçekleşmesinde gerekli olduğunu bilmeleri yararlı olacaktır. 


\section{Kaynaklar / References}

Amir, R., \& Tamir, P. (1994). In depth analysis of misconceptions as a basis for developing study-based remedial instruction: The case of photosynthesis. The American Biology Teacher, 56, 94-100.

Boud, D. J. (1989). Individualized instruction in higher education. The International Enclopedia of Educational Technology. UK: Wheatons Ltd.

Brooker, R. J., Widmaier, E. P., Graham, L. E., \& Stiling, P. D. (2008). Membrane structure and transport: Biology. New York: Mcgraw-Hill.,

Brown, C. R. (1995). The effective teaching of biology. London: Longman.

Büyüköztürk, Ş., Çakmak, E. K., Akgün, Ö. E., Karadeniz, Ş., \& Demirel, F. (2017). Bilimsel araştırma yöntemleri. Ankara: Pegem.

Dikmenli, M., Türkmen, L., Çardak, O., \& Kurt, H. (2005). Biyoloji öğretmen adaylarının bazı Genel Biyoloji konularındaki kavram yanılgılarının iki aşamalı çoktan seçmeli bir araç ile belirlenmesi. Dokuz Eylül Üniversitesi Buca Ĕ̈itim Fakültesi Dergisi, 17, 365-370.

Duruhan, K. (2004). Türkiye'de okulda geleneksel anlayış ve yöntemlerle insan yetiştirmenin olumsuz etkileri. XIII. Ulusal Ĕgitim Bilimleri Kurultayı, İnönü Üniversitesi, Malatya.

Etobro, A. B., \& Banjoko, S. O. (2017). Misconceptions of genetics concepts among pre-service teachers. Global Journal of Educational Study, 16(2), 121-128.

Fisher, K. M. (1985). A misconception in biology: Amino acids and translation. Journal of Research in Science Teaching, 22(1), 53-62.

Gökkurt Özdemir, B, Bayraktar, R, \& Yılmaz, M. (2017). Sınıf ve matematik öğretmenlerinin kavram yanılgılarına ilişkin açıklamaları. Trakya Üniversitesi Eğitim Fakültesi Dergisi, 7(2), 284-305.

Gündüz, E., Yılmaz, M., \& Çimen, O. (2016). MEB ortaöğretim 10. sınıf biyoloji ders kitabının bilimsel içerik bakımından incelenmesi. Bayburt Ĕgitim Fakültesi Dergisi, 11(2), 414-430

Gündüz, E., Yılmaz, M., Çimen, O., \& Şen, U. (2017). MEB ortaöğretim 11. sınıf biyoloji ders kitabının bilimsel içerik bakımından incelenmesi. Gazi Üniversitesi Gazi Ĕgitim Fakültesi Dergisi, 37(3), 1115-1140.

Harman, G. (2014). Hücre zarından madde geçişi ile ilgili kavram yanılgılarının tahmin-gözlem-açıklama yöntemiyle belirlenmesi. Journal of Turkish Science Education, 11(4), 81-106.

Hickman, C. P., Roberts, L. S., Keen, S. L., Eisenhour, D. J., Larson, A., \& I'Anson, H. (2016). Zooloji entegre prensipler. (Çev. Ed. E. Gündüz). Ankara: Palme.

Kaya, F. (2010). Fen bilgisi ögretmen adaylarında fotosentez ve bitkilerde solunum konularında görülen kavram yanılgılarının giderilmesinde bilgisayar destekli kavramsal değişim metinlerinin etkisi (Yayınlanmamış yüksek lisans tezi). Pamukkale Üniversitesi, Denizli.

Kırbaşlar, F. G., Çıngıl Barış, Ç., \& Ünal, M. (2009). Fen bilgisi öğretmen adaylarının fermentasyon konusundaki yanlış öğrenmelerinin araştırılmasına yönelik bir çalışma. Hacettepe Üniversitesi Eğitim Fakültesi Dergisi, 36, 158-168.

Kirk, J., \& Miller, M. (1986). Reliability and validity in qualitative study. Newbury Park, CA: Sage Publications.

Kirkpatrick, G., \& Orvis, K. (2002). A teaching model for biotechnology and genomics education. Journal of Biological Education, 37(1), 31-35.

Klug, W. S., \& Cummings, M. R. (2003). Concepts of genetics (No. Ed. 7). Upper Saddle River, NJ: Pearson Education.

LeCompte, M. D., \& Goetz, J. P. (1982). Problems of reliability and validity in ethnographic research. Review of Educational Research, 52(1), 31-60.

Mader, S. S., \& Windelspecht, M. (2018). Essentials of biology (5th ed.). New York, NY: Mcgraw-Hill Education. 
Madigan, M. T., Martinko, J. M., \& Parker, J. (2010). Brock biology of microorganisms (13th ed.). San Francisco, CA: Benjamin Cummings.

Miles, M. B., \& Huberman, A. M. (2015). Nitel veri analizi: Genişletilmiş bir kaynak kitap (Çev. Ed. S. Akbaba Altun \& A. Ersoy). Ankara: Pegem Akademi.

Milli Eğitim Bakanlı̆̆ (MEB). (2017). Öğretmen mesleği genel yeterlikleri. Erişim: https://oygm.meb.gov.tr/meb_iys_dosyalar/2017_12/11115355_yyretmenlyk_mesleyy_genel_yeterlyklery.pdf

Montfort, D., Brown, S., \& Findley, K. (2007). Using interviews to identify student misconceptions in dynamics. In the proocedings of the 37th Annual Frontiers in Education Conference - Global Engineering: Knowledge Without Borders, Opportunities Without Passports (pp. s3d-22).

Mulholland, J., \& Ginns, I. (2008). College moon project Australia: Preservice teachers learning about the moon's phases. Study in Science Education, 38, 385-399.

Nelson, D. L., Lehninger, A. L., \& Cox, M. M. (2008). Lehninger Principles of Biochemistry. London: Macmillan.

Pashley, M. (1994). A chromosome model. Journal of Biological Education, 28(3), 157-161.

Reece, J. B., Urry, L. A., Cain, M. L., Wasserman, S. A., Minorsky, P. V., \& Jackson, R. B. (2013). Campbell biyoloji (Çev. Ed. İ. Türkan \& E. Gündüz). Ankara: Palme.

Riche, R. D. (2000). Strategies for assisting students overcome their misconceptions in high school physics. Memorial University of Newfoundland Education, 63-90.

Rowell, A. J., Dawson, C. J., \& Harry, L. (1990). Changing misconceptions: A challenge to science education. International Journal Science Education. 12(2), 167-175

Sadava, D., Hillis, M. D., Heller, H. C., \& Berenbaum, M. R. (2014). Yaşam bilimi biyoloji (Çev. Ed. E. Gündüz \& İ. Türkan). Ankara: Palme.

Simon, E. J., Dickey, J. L., Hogan, K. A., \& Reece, J. B. (2017). Campbell temel biyoloji (Çev. Ed. E. Gündüz \& İ. Türkan) Ankara: Palme.

Tatar, N., \& Cansüngü Koray, Ö. (2005). İlköğretim 8. sınıf öğrencilerinin “genetik” ünitesi hakkındaki kavram yanılgılarının belirlenmesi. Kastamonu Ĕgitim Dergisi, 13(2), 415-426.

Tekkaya, C., Çapa, Y., \& Yılmaz, Ö. (2014). Biyoloji öğretmen adaylarının Genel Biyoloji konularındaki kavram yanılgıları. Hacettepe Üniversitesi Ĕ̈itim Fakültesi Dergisi, 18, 140-147.

Tertemiz, N. (2011). Tam ögrrenme modeli ya da okulda öğrenme kuramı: Öğrenme öğretme kuram ve yaklaşımları. Ankara, PegemA.

Vitharana, P. R. K. A. (2015). Student misconceptions about plant transport-A Sri Lankan example. European Journal of Science and Mathematics Education, 3(3), 275-288.

Yıldırım, A., \& Şimşek, H. (2005). Sosyal bilimlerde nitel araştırma yöntemleri. Ankara: Seçkin.

Yılmaz, M., Çimen, O., Karakaya, F., \& Adıgüzel, M. (2018). Biyoloji öğretmen adaylarının ortaöğretim biyoloji dersi ünite/konularına yönelik öz-yeterlik algılarının incelenmesi. Ihlara Ĕgitim Araştırmaları Dergisi, 3(2), 145-154.

Yılmaz, M., Gündüz, E., Diken, E., \& Çimen, O. (2017). 8. sınıf fen bilimleri ders kitabındaki biyoloji konularının bilimsel içerik açısından incelenmesi. Erzincan Üniversitesi Eğitim Fakültesi Dergisi, 19(3), 17-35.

Yürük, N., \& Çakır, Ö. S. (2000). Lise öğrencilerinde oksijenli ve oksijensiz solunum konusunda görülen kavram yanılgılarının saptanmas1. Hacettepe Üniversitesi Ĕ̆itim Fakültesi Dergisi, 18(18), 1-5. 